\title{
KEBERADAAN MATERIAL BAMBU SEBAGAI SUBTITUSI MATERIAL KAYU PADA PENERAPAN DESAIN INTERIOR DAN ARSITEKTUR
}

\author{
Grace Hartanti \\ Jurusan Desain Interior, Fakultas Komunikasi Multimedia, Universitas Bina Nusantara \\ Jln. K.H. Syahdan No.9, Palmerah, Jakarta Barat 11480 \\ gracehartanti@yahoo.com
}

\begin{abstract}
Wood is a building material that is frequently used as the main component in interior design and architecture. But, the use of wood is declining today and it is replaced by bamboo. Now, wood material is difficult to find and this condition causes high price in market. Article presents the availability of bamboo that has been known by our society because of its benefit. They use bamboo to meet their everyday life, such as clothes, food, and house needs. Bamboo is also used for the development of interior design as well as architecture, especially in Indonesia.
\end{abstract}

Keywords: interior design, architecture, bamboo

\begin{abstract}
ABSTRAK
Kayu merupakan bahan bangunan yang paling sering digunakan sebagai komponen utama dalam penerapan desain interior dan arsitektur. Namun, saat ini penggunaan fungsi kayu pada bangunan sudah mulai tergantikan dengan bahan material lain karena keberadaan kayu yang sudah semakin langka sehingga menyebabkan tingginya harga yang ditawarkan. Salah satunya material penggantinya adalah bambu. Artikel menjelaskan keberadaan bambu yang sudah dikenal masyarakat karena banyaknya manfaat yang dapat digunakan dalam kehidupan sehari-hari (meliputi kebutuhan sandang, pangan, dan papan) dan telah banyak diterapkan pada perkembangan desain interior dan arsitektur, khususnya di Indonesia.
\end{abstract}

Kata kunci: desain interior, arsitektur, bambu 


\section{PENDAHULUAN}

Bergulirnya roda waktu, yaitu meningkatnya taraf kehidupan masyarakat, berpengaruh pada perkembangan desain interior dan arsitektur di Indonesia. Ini menyebabkan tingginya permintaan pada lingkungan industri building contruction dan interior/household manufactur. Material kayu diketahui sebagai salah satu material utama yang banyak digunakan pada perkembangan industri. Sejalan dengan berkembang pesatnya industri, kayu memiliki masa pertumbuhan yang relatif lama sehingga sampai menebangnya dapat memakan waktu puluhan bahkan ratusan tahun. Dengan demikian, keberadaan kayu akan semakin langka. Oleh karena itu, penggunaan material kayu mulai tergantikan dengan material lain; salah satu contohnya adalah material bambu.

Bambu merupakan sumber bahan bangunan yang terbarukan dan banyak tersedia di Indonesia. Dari sekitar 1.250 jenis bambu di dunia, 140 jenis atau 11\% nya adalah spesies asli Indonesia. Orang Indonesia sudah lama memanfaatkan bambu untuk bangunan rumah, perabotan, alat pertanian, kerajinan, alat musik, dan makanan. Namun, bambu belum menjadi prioritas pengembangan dan masih dilihat sebagai "bahan milik kaum miskin yang cepat rusak". Namun, sesuai dengan perkembangan teknologi dan ilmu pengetahuan, sudah hadir beberapa perusahaan yang mengangkat citra bambu dengan menghasilkan produk berkualitas yang indah, kuat, dan tahan lama. Bambu yang dipanen dengan benar dan diawetkan merupakan bahan yang kuat, fleksibel, dan murah, yang dapat dijadikan bahan alternatif pengganti kayu yang semakin langka dan mahal.

\section{METODE PENELITIAN}

Artikel berdasarkan studi literature, yaitu mencari berbagai sumber yang terkait dengan bambu dari perpustakaan dan internet. Sumber informasi diseleksi, dievaluasi, dan dijadikan pendukung artikel ini.

\section{HASIL DAN PEMBAHASAN}

\section{Pengenalan Bambu}

Bambu merupakan kelompok tanaman yang pertumbuhannya paling cepat di dunia, yaitu mencapai lebih dari $60 \mathrm{~cm}$. per hari, tergantung kondisi tanah dan iklim setempat. Bambu dapat tumbuh baik di iklim tropis seperti Indonesia. Ketinggian pohon bambu bervariasi, dari $100 \mathrm{~cm}-300$ $\mathrm{cm}$, dengan diameter kayu antara 7,5 cm $-18 \mathrm{~cm}$.

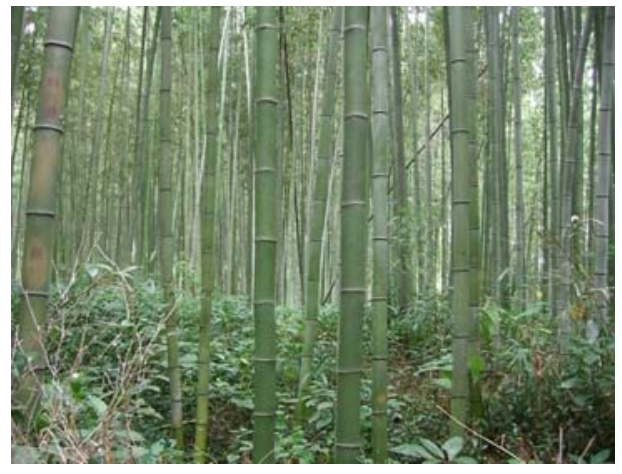

Gambar 1 Kelompok Tanaman Bambu 1

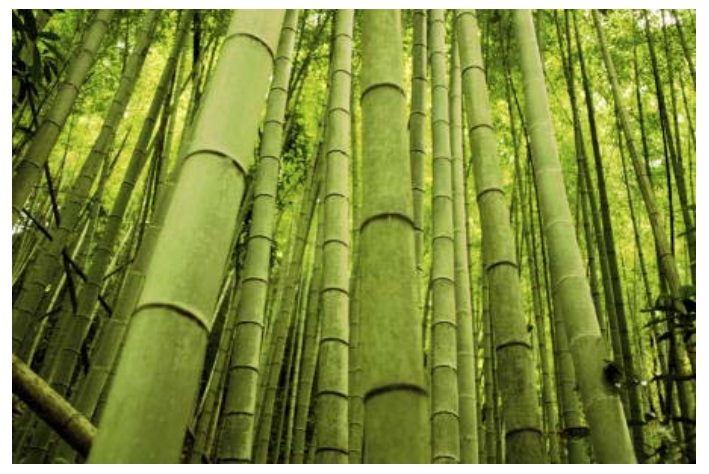

Gambar 2 Kelompok Tanaman Bambu 2 
Batang bambu tidak seperti batang pohon lain karena mempunyai struktur yang hollow (kosong) di bagian dalamnya.

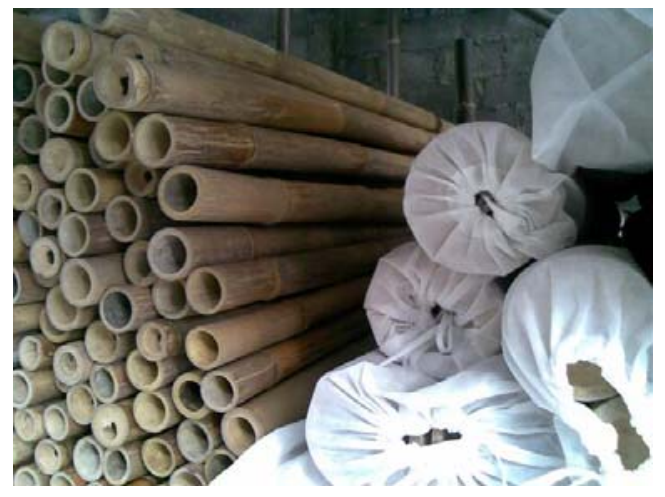

Gambar 3 Struktur Hollow pada Bambu

\section{Keuntungan Bambu}

Keuntungan bambu adalah sebagai berikut. Pertama, masa tumbuh bambu paling cepat, yaitu lima tahun bisa dipanen. Kayu butuh belasan sampai puluhan tahun untuk panen. Selain itu, budi dayanya hanya dengan sekali tanam. Kedua, bambu terus berkembang biak dengan rhizom (akar yang menjadi tunas baru). Akar bambu menjalar di lapisan permukaan tanah atas. Bambu mereduksi kemungkinan erosi, jadi cocok ditanam di kemiringan permukaan tanah untuk menghindari bencana longsor. Ketiga, akar bambu menyerap polutan tanah dan memperbesar cadangan air. Di sempadan sungai, keberadaan rumpun bambu akan menjernihkan air. Akar bambu bisa dipetik menjadi sumber pangan, yaitu rebung dan tunas bambu muda. Keempat, ekspor bambu sebagai substitusi kayu ke Eropa bisa menepis hambatan persyaratan ecolabelling atau tingkat keramahan terhadap ekologi karena ketika tidak dimanfaatkan bambu akan membusuk dan melepas emisi. Kelima, bambu bisa menjadi bahan baku tisu, kertas, dan tekstil. Tisu dari bambu tidak mudah sobek. Ada kaus kaki dan celana dalam berbahan 95\% bambu. Tekstil bambu itu lembut, dingin, tipis, dan kuat. Bambu dapat diolah menjadi fiber atau serat. Tak ubahnya biji plastik, fiber bambu mudah dibentuk. Keenam, bambu juga ramah pemanasan global karena fotosintesis bambu tergolong paling efisien. Dalam respirasi bambu dapat menyerap kembali karbondioksida yang dihasilkan dengan rantai karbon C. Ketujuh, bambu memiliki kekuatan yang dapat dipersaingkan dengan baja. Dikarenakan kelenturan dan kekuatannya yang tinggi, struktur bambu juga merupakan bangunan tahan gempa.

\section{Pemanenan Bambu}

Tanaman bambu di Indonesia merupakan tanaman bambu simpodial, yaitu batang-batangnya cenderung mengumpul di dalam rumpun karena percabangan rhizomnya di dalam tanah cenderung mengumpul. Batang bambu yang lebih tua berada di tengah rumpun, sehingga kurang menguntungkan dalam proses penebangan.

Metode pemanenan tanaman bambu adalah dengan metode tebang habis dan tebang pilih. Pada metode tebang habis, semua batang bambu ditebang, baik yang tua maupun yang muda sehingga kualitas batang bambu yang diperoleh bercampur antara bambu yang tua dan yang muda. Selain itu, metode ini juga menimbulkan pengaruh terhadap sistem perebungan bambu sehingga kelangsungan tanaman bambu terganggu karena sistem perebungan bambu dipengaruhi juga oleh batang bambu yang ditinggalkan. Pada beberapa jenis tanaman bambu, metode tebang habis menyebabkan rumpun menjadi kering dan mati. Pada jenis yang lain masih mampu menumbuhkan rebungnya, tetapi dengan 
diameter rebung tidak besar dan jumlahnya tidak banyak. Metode pemanenan lain, yaitu tebang pilih, merupakan bambu yang ditebang dipilih yang tua dan siap untuk ditebang.

\section{Pengawetan Bambu}

Usaha pengawetan bambu secara tradisional sudah dikenal oleh masyarakat pedesaan. Pengawetan dilakukan dengan cara merendam bambu di dalam air mengalir, air tergenang, lumpur atau di air laut, dan pengasapan. Selain itu, juga sering ditemukan cara pengawetan dengan pelaburan kapur dan kotoran sapi pada gedek dan bilik bambu.

Penelitian pengawetan bambu dengan menggunakan bahan kimia, disertai metode yang tepat dan efisien terus dilakukan. Pengawetan bambu bertujuan mencegah serangan jamur (pewarna dan pelapuk) maupun serangga (bubuk kering, rayap kayu kering, dan rayap tanah). Beberapa pengrajin mebel bambu telah melaksanakan pengawetan dengan menggunakan boraks, campuran kapur barus dengan minyak tanah atau pengasapan dengan belerang. Namun, sesuai dengan berjalannya waktu, yaitu perkembangan ilmu pengetahuan dan teknologi sudah berkembang dengan pesat, terdapat metode pengawetan bambu, yakni dengan menggunakan sistem Vertical Soak Diffusion (VSD) menggunakan bahan pengawet (larutan borate) yang ramah lingkungan dan aman bagi kesehatan. Sistem VSD ini awal mulanya dikembangkan oleh EBF Bali. Metode VSD terbukti efektif melindungi bambu dari serangan kumbang bubuk dan rayap hingga puluhan tahun. Selain itu, juga terdapat metode terbaru pengawetan dengan menggunakan tangki bertekanan yang dapat mengawetkan berbagai jenis dan ukuran bambu secara lebih cepat.

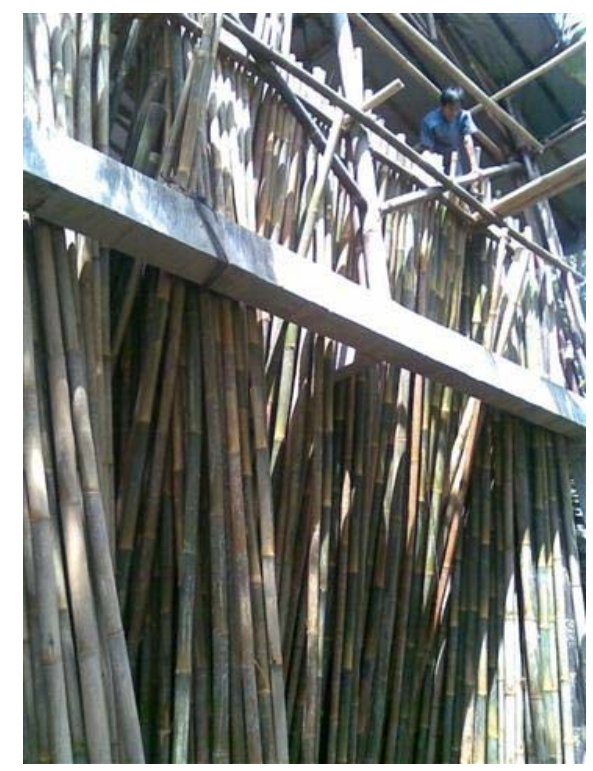

Gambar 4 Pengisian Larutan untuk Peredaman Vertikal Bambu (Pengawetan 1)

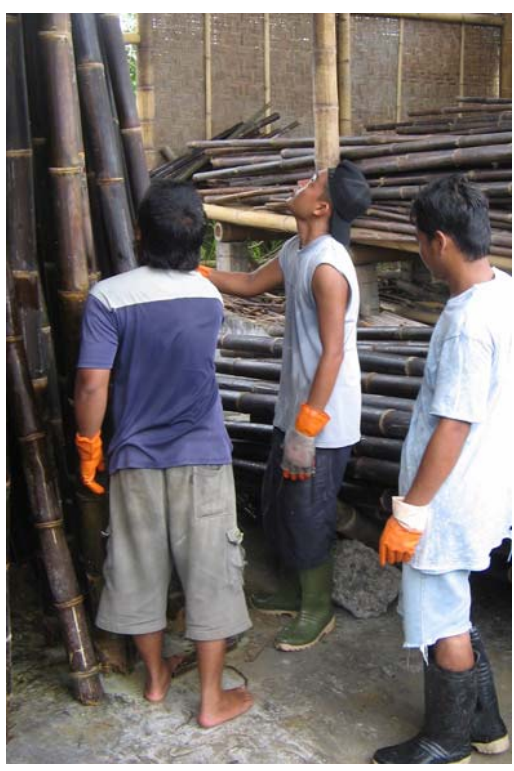

Gambar 5 Pengisian Larutan untuk Peredaman Vertikal Bambu (Pengawetan 2) 


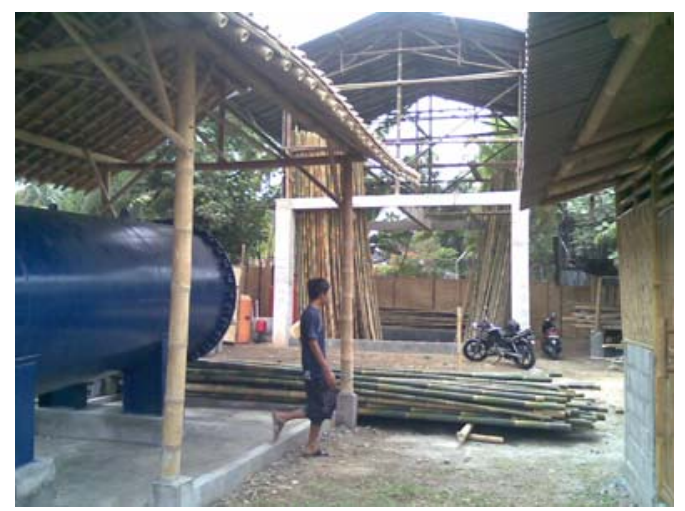

Gambar 6 Tangki Pengawetan Bambu

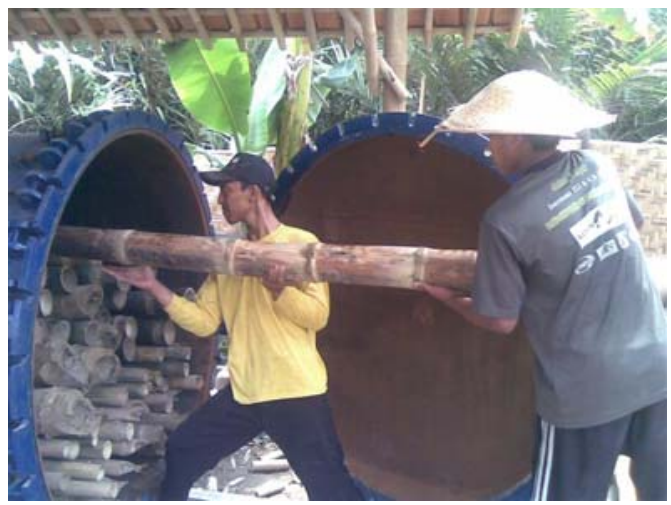

Gambar 7 Bambu pada Tangki Bertekanan

\section{Jenis Bambu yang Bernilai Ekonomi}

Berikut ini jenis bambu yang bernilai ekonomi, di antaranya adalah sebagai berikut. Pertama, bambusa bambos. Nama lokalnya adalah bambu ori, jawanya adalah pring ori. Dengan tinggi berdiameter dan warna batang. Tinggi mencapai $30 \mathrm{~m}$ (dinding batang sangat tebal dan batang berbulu tebal); 15 - $18 \mathrm{~cm}$ (jarak buku 20 - $40 \mathrm{~cm}$ ); berwarna hijau muda; tempat tumbuhnya di tanah basah, di sepanjang sungai. Manfaatnya adalah: rebungnya (sayuran), daunnya (makanan ternak), dan bibitnya (bahan makanan sekunder), sampai dengan batangnya (keperluan rumah tangga dan bahan dasar bangunan). Jenis ini berguna sebagai pengendali banjir bila ditanam di sepanjang sungai dan pelindung tanaman dari angin kencang. Batangnya dipakai untuk industri pulp, kertas, dan kayu lapis. Jenis ini juga dapat dipakai sebagai bahan dasar pembuatan semir sepatu, lem perekat, kertas karbon, dan kertas kraft tahan air. Rendaman daun bambu dipakai untuk penyejuk mata dan mengobati penyakit (bronkitis, demam, dan gonorrhoea).

Kedua, bambusa vulgaris Schrader ex Wendland. Nama lokalnya adalah pring ampel, bambu ampel, haur. Dengan tinggi berdiameter dan warna batang; tinggi mencapai 10 - $20 \mathrm{~m}$ (batang berbulu sangat tipis dan tebal dinding batang 7 - 15 m; 4 - $10 \mathrm{~cm}$ (jarak buku 20 - $45 \mathrm{~cm}$ ); kuning muda bergaris hijau tua. Tempat tumbuhnya, mulai dataran rendah hingga ketinggian $1200 \mathrm{~m}$, di tanah marjinal atau di sepanjang sungai, tanah genangan, $\mathrm{pH}$ optimal 5 - 6,5; serta tumbuh paling baik pada dataran rendah. Manfaatnya adalah air rebusan rebung muda bambu kuning dimanfaatkan untuk mengobati penyakit hepatitis. Batangnya banyak digunakan untuk industri, mebel, bangunan, perlengkapan perahu, pagar, tiang bangunan, dan juga sangat baik untuk bahan baku kertas.

Ketiga, dendrocalamus asper (Schultes f.) Backer ex Heyne. Nama lokalnya adalah bambu petung, buluh betung, bulu jawa, dan betho. Tinggi mencapai 20 - $30 \mathrm{~m}$ (batang berbulu tebal dan tebal dinding batang 11 - $36 \mathrm{~m}$ ); diameter berukuran 8 - $20 \mathrm{~cm}$ (jarak buku $10-20 \mathrm{~cm}$ di bagian bawah dan 30 - $50 \mathrm{~cm}$ di bagian atas); warna batangnya adalah coklat tua. Tempat tumbuhnya, mulai dataran rendah hingga ketinggian $1500 \mathrm{~m}$, tumbuh terbaik pada ketinggian antara 400 - $500 \mathrm{~m}$, dengan curah hujan tahunan sekitar $2400 \mathrm{~mm}$. Tumbuh di semua jenis tanah, tetapi paling baik di tanah yang berdrainase baik. Manfaatnya adalah rebung dari jenis tanaman bambu ini adalah rebung yang terbaik dengan rasa manis dibuat untuk sayuran. Batangnya digunakan untuk bahan bangunan (perumahan dan jembatan), peralatan memasak, bahkan juga untuk penampung air. Banyak digunakan untuk konstruksi rumah, atap dengan disusun tumpang-tindih, dan dinding dengan cara dipecah dibuat plupu.

Keempat, dendrocalamus strictus (Roxb.) Nees. Nama lokalnya adalah bambu batu. Tinggi mencapai 8 - $16 \mathrm{~m}$ (batang berbulu tebal dan tebal dinding batang hingga $1 \mathrm{~cm}$ ); diameter berukuran 2,5 - 12,5 cm (jarak buku 30 - $45 \mathrm{~cm}$ ); warna batangnya adalah hijau, kekuningan, buram. Tempat 
tumbuhnya di segala jenis tanah, khususnya tanah liat berpasir, dengan drainase yang baik dengan $\mathrm{pH}$ 5,5 - 7,5. Ketinggian dari permukaan laut sampai dengan 1200 dengan curah hujan optimal per tahun 1000 - 3000 mm. Manfaatnya adalah digunakan untuk bahan industri pulp dan kertas, kayu lapis, bangunan, mebel, anyaman, peralatan pertanian, dan peternakan. Sedangkan daunnya digunakan untuk makanan ternak.

Kelima, gigantochloa apus (J.A \& J.H. Schultes) Kurz. Nama lokalnya adalah bambu apus, pring apus, peri. Tinggi mencapai 8 - $30 \mathrm{~m}$ (batang berbulu tebal dan tebal dinding batang 1,5 cm; diameter berukuran 4 - $13 \mathrm{~cm}$ (jarak buku 20 - 75cm.); warna batangnya adalah hijau keabu-abuan, cenderung kuning mengkilap. Tempat tumbuhnya di dataran rendah, dataran tinggi (atau berbukitbukit) sampai dengan $1.500 \mathrm{~m}$, bahkan juga dapat tumbuh di tanah liat berpasir. Manfaatnya adalah biasa digunakan sebagai tanaman pagar penghias. Batangnya juga dapat dipakai sebagai alat pembuatan pegangan payung, peralatan memancing, kerajinan tangan (rak buku), industri pulp dan kertas, dan penghalau angin kencang (wind-break).

Keenam, gigantochloa atroviolacea Widjaja. Nama lokalnya adalah bambu hitam, pring wulung, peri laka. Tinggi mencapai $2 \mathrm{~m}$ (batang berbulu tipis/halus dan tebal, dinding batang hingga 8 $\mathrm{mm}$ ); diameter berukuran 6 - $8 \mathrm{~cm}$ (jarak buku $4 \mathrm{~cm} .-50 \mathrm{~cm}$ ); warna batangnya adalah hijau-coklat tua, keunguan atau hitam. Tempat tumbuhnya adalah di tanah tropis dataran rendah, berlembab, dengan curah hujan per tahun mencapai 1500 - $3700 \mathrm{~mm}$, dengan kelembaban relatif sekitar $70 \%$ dan temperatur $20-32^{\circ} \mathrm{C}$. Dapat pula tumbuh di tanah kering berbatu atau tanah (vulkanik) merah. Jika ditanam di tanah kering berbatu, warna ungu pada batang akan kelihatan semakin jelas. Manfaatnya adalah digunakan untuk bahan pembuatan instrumen musik seperti angklung, calung, gambang, dan celempung. Juga berfungsi untuk bahan industri kerajinan tangan dan pembuatan mebel. Rebungnya dapat dimanfaatkan sebagai sayuran.

Ketujuh, gigantochloa pseudoarundinacea (Steudel) Widjaja. Nama lokalnya adalah bambu andong, gambang surat, peri. Tinggi mencapai 7 - $30 \mathrm{~m}$ (batang berbulu tebal dan tebal dinding batang hingga $2 \mathrm{~cm}$ ); diameter 5 - $13 \mathrm{~cm}$ (jarak buku hingga $40-45 \mathrm{~cm}$ ); warna batangnya adalah hijau kehijau, kuningan atau hijau muda. Tempat tumbuhnya di tanah liat berpasir/tanah berpasir, dengan ketinggian hingga $1.200 \mathrm{~m}$ di atas permukaan laut dengan curah hujan per tahun $2.350-4.200 \mathrm{~mm}$, temperatur $20-32{ }^{\circ} \mathrm{C}$, dengan tingkat kelembaban relatif sekitar 70\%. Manfaatnya adalah digunakan untuk bahan bangunan, pipa air, mebel, peralatan rumah tangga, sumpit makan, tusuk gigi, dan peralatan musik. Rebungnya dapat dimasak menjadi sayuran.

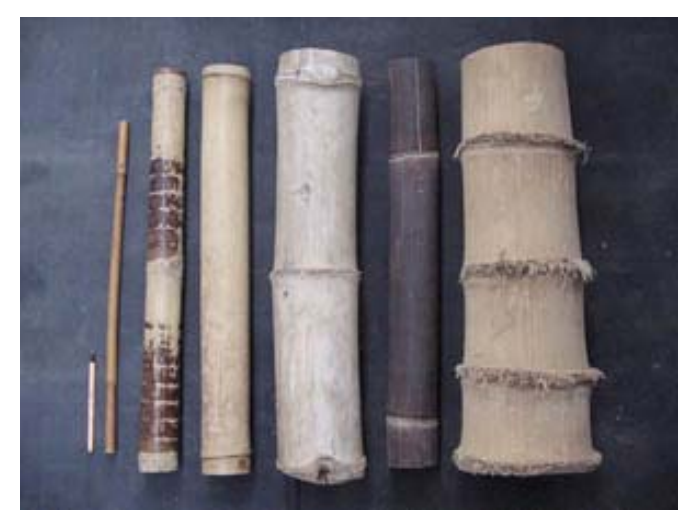

Gambar 8 Jenis Bambu untuk Konstruksi Bangunan, Mebel, dan Kerajinan Tangan (dari kanan ke kiri: petung, wulung, ori, apus, tutul, dan cendani) 


\section{Penerapan Material Bambu pada Desain Interior dan Arsitektur}

\section{Showroom dan Office}

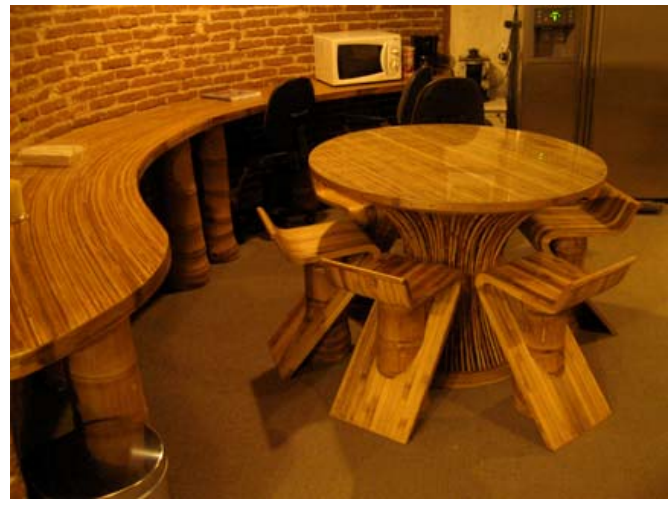

Gambar 9 Meja Staf, Meja dan Kursi Rapat

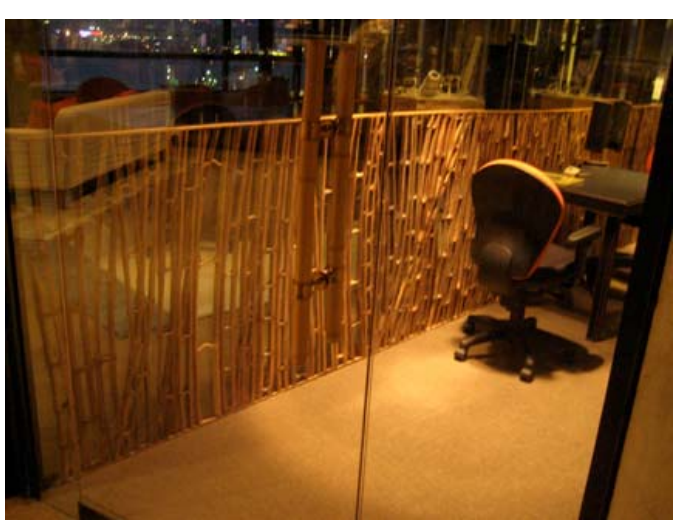

Gambar 11 Partisi bambu

\section{Pengerjaan Bambu untuk Residensial}

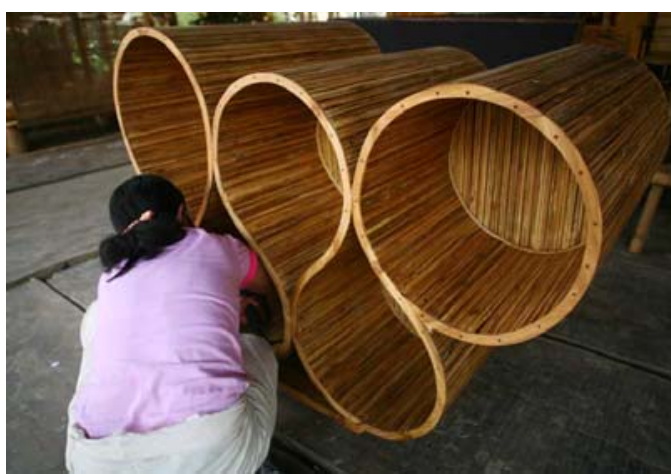

Gambar 13 Pembuatan Kaki Meja 1

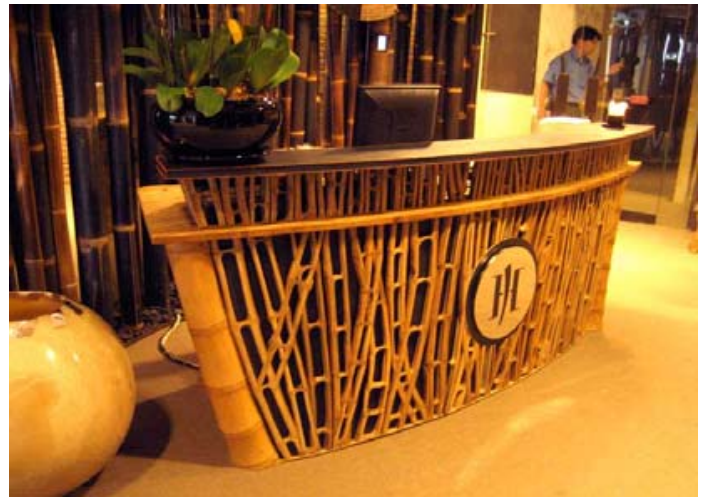

Gambar 10 Meja Penerima Tamu

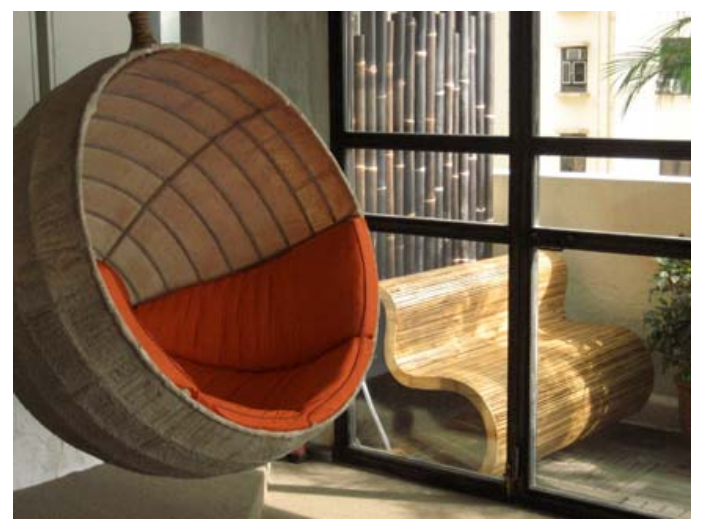

Gambar 12 Sofa Bambu

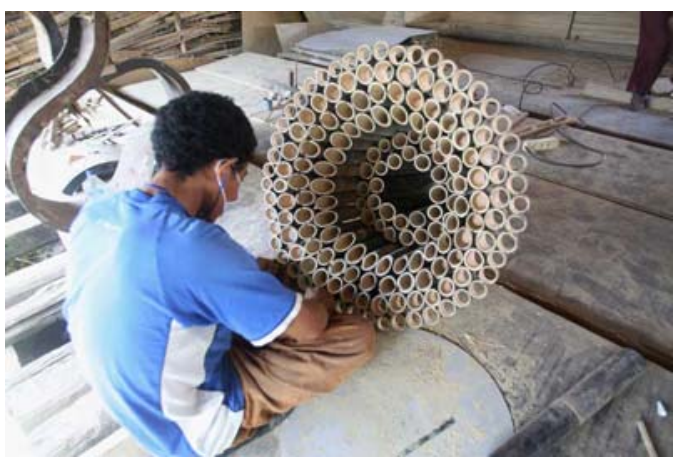

Gambar 14 Pembuatan Kaki Meja 2 


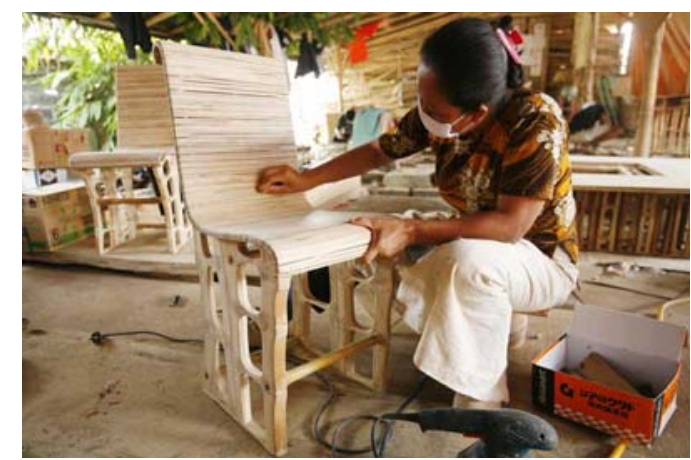

Gambar 15 Pembuatan kursi makan

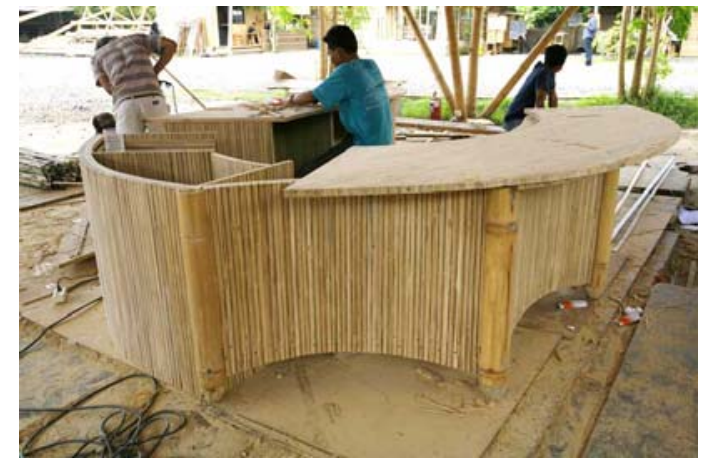

Gambar 16 Pembuatan pantry

\section{Hasil Penerapan Bambu pada Desain Arsitektur}

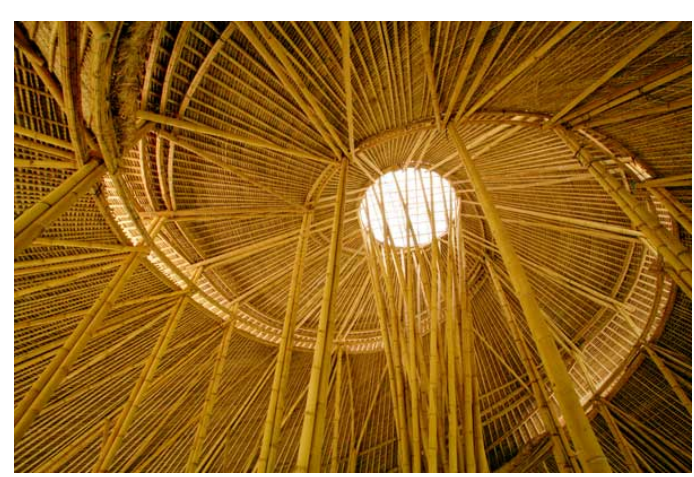

Gambar 17 Konstruksi Bangunan Bambu

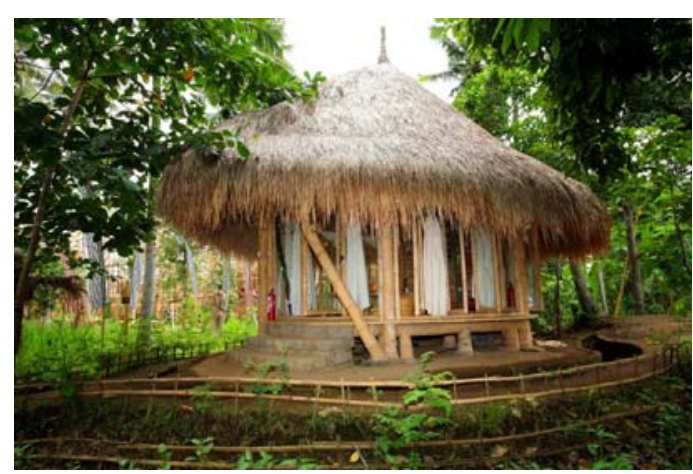

Gambar 19 Arsitektur dari Bambu 1

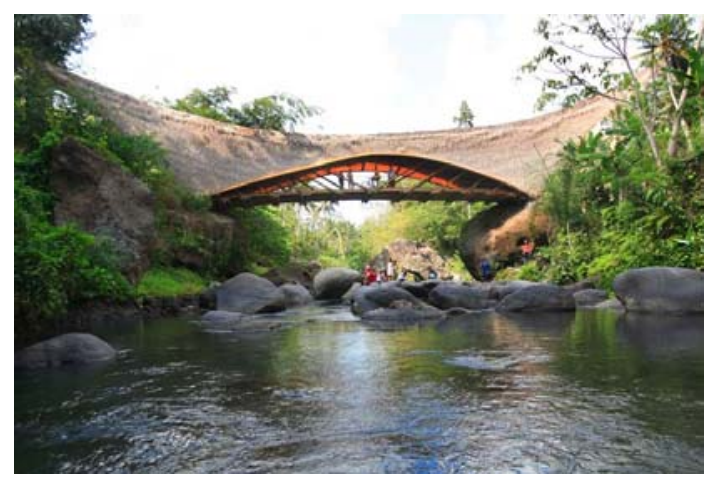

Gambar 18 Jembatan Bambu

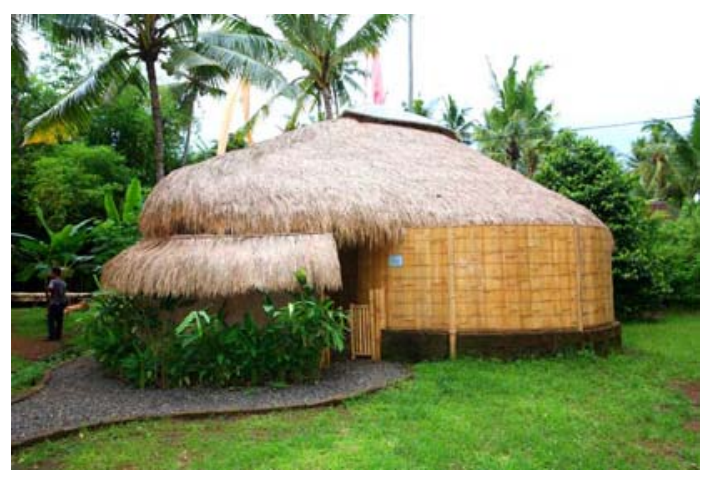

Gambar 20 Arsitektur dari Bambu

\section{SIMPULAN}

Material bambu memiliki banyak sekali manfaat yang dapat diperoleh, baik pada masa pertumbuhan serta penerapannya sebagai material pada industri yang bergerak di bidang desain interior dan srsitektur. Dengan perkembangan zaman yang ada, disertai kemajuan teknologi dan sumber daya manusia yang kian lama kian berkembang, kelangkaan material kayu telah dapat digantikan oleh material bambu dengan mempertimbangkan segala aspek yang ada, terutama segi efektivitas dan efisiensi produksi. 
Namun, selayaknya material yang dipergunakan untuk industri, penggunaan bambu dibutuhkan dalam jumlah besar. Dengan demikian, diharapkan masyarakat tidak lupa untuk melakukan reboisasi terhadap tumbuhan bambu. Bahkan, sejalan dengan perkembangan waktu, informasi menunjukkan adanya perkembangan terbaru untuk melipatgandakan bibit bambu dengan menggunakan bioteknologi kloning. Sedangkan teknologi konvensional pembibitan bambu di Indonesia dilakukan dengan setek. Teknologi ini diperkirakan hanya mampu memperbanyak sampai belasan atau puluhan bibit bambu setiap tahun. Sistem kloning menggunakan metode turunan individu; bukan secara generatif, melainkan dengan memberikan rangsangan hormon pengatur tumbuh pada bagian tertentu yang dipungut dari tubuh utuh makhluk hidup. Hasilnya tentu serupa dengan induknya yang telah dipilih dari tanaman bambu paling baik. Cara ini diharapkan dapat mempertahankan ekosistem bambu. Dengan terpeliharanya ekosistem bambu, keuntungan yang diperoleh tidak hanya dalam industri desain interior dan arsitektur, tetapi juga menjaga ekosistem alamiah. Hal ini membawa dampak positif seperti mereduksi erosi dan meredam pemanasan global, dan lain lain yang dapat membawa keuntungan bagi segenap pihak.

\section{DAFTAR PUSTAKA}

Anonim. (2008). Sahabat bambu. Diakses dari http://www.sahabatbambu.com.

Hardy, J. (2009). PT Bambu. Diakses dari http://www.ptbambu.com.

Morisco. (2005). Rangkuman penelitian bambu di Pusat Studi Ilmu Teknik UGM (1994 2004). Prosiding seminar perkembangan bambu Indonesia, Yogyakarta.

Sumantera, I. W., dan I. N. Peneng. (2005). Pemberdayaan hutan bambu sebagai penunjang sosial ekonomi masyarakat Desa Pakraman Angseri, Tabanan, Bali. Prosiding seminar perkembangan bambu Indonesia, Yogyakarta.

Tunggal, N. (2010). Kloning lipatgandakan bambu. Diakses dari http://cetak.kompas.com/read/xml/2010/02/05/04335469/kloning.lipat.gandakan.bambu

Widjaja, E. A. (2001). Identikit jenis-jenis bambu di Kepulauan Sunda Kecil, Bogor: Puslitbang Biologi LIPI.

Widjaja, E. A. (2001). Identikit jenis-jenis bambu di Jawa, Bogor: Puslitbang Biologi LIPI.

Widjaja, E. A., N. W. Utami., dan Saefudin. (2004). Panduan membudidayakan bambu, Bogor: Puslitbang Biologi LIPI. 